\title{
To Study Hydrogeology and Wetland-Groundwater Interactions around Sukhna Wetland, Chandigarh, India
}

\author{
Jasbir Kaur Taak ${ }^{1^{*}}$, Singh $\mathrm{KP}^{2}$ and Ahluwalia $\mathrm{AS}^{3}$ \\ ${ }^{1}$ Department of Environment Studies, Panjab University, Chandigarh, India \\ ${ }^{2}$ Department of Geology, Panjab University, Chandigarh, India \\ ${ }^{3}$ Department of Botany, Panjab University, Chandigarh, India
}

*Corresponding author: Taak JK, Department of Environment Studies, Panjab University, Chandigarh-160 014, India, Tel: 08566966045; E-mail: jastaak86@gmail.com Rec date: Mar 31, 2016; Acc date: May 17, 2016; Pub date: May 24, 2016

Copyright: $\odot 2016$ Taak JK, et al. This is an open-access article distributed under the terms of the Creative Commons Attribution License, which permits unrestricted use, distribution, and reproduction in any medium, provided the original author and source are credited.

\begin{abstract}
In the present paper the hydrological regime around Sukhna wetland is studied to know how a wetland is functioning, its influence on hydrology of the area and wetland-groundwater interactions. The subsurface geology of boreholes drilled around Sukhna wetland reveals thick zones of boulders, pebbles, gravels, sand and clay at different depths. In this area there are two type aquifer systems i.e., shallow and deep. The depth for shallow aquifer ranged $2-20 \mathrm{~m} \mathrm{bgl}$ and in deeper aquifers ranged 10 above $40 \mathrm{~m}$ bgl. The water level fluctuations for the period 1985-2013, indicates the declining water level trend in both the seasons i.e., pre monsoon (May) and post monsoon (November) due to over exploitation by tubewells installed by the Public Health Department, UT, Chandigarh for providing domestic water supply. The water table elevation contour maps for May and November months in Chandigarh for years 1986, 1991, 1999, 2005 and 2012 reveals that the regional ground water flow direction is from Northeast to Southwest and there in no significant temporal variations in regional ground water flow direction. On the basis of hydrological regime study around Sukhna wetland it is inferred that no appreciable rise in water levels has been observed around Sukhna wetland but it is contributing recharge in the upper shallow aquifer system in the central part of Chandigarh and below as the subsurface groundwater flow is towards south and south west direction.
\end{abstract}

Keywords: Wetland; Groundwater; Sukhna; Hydrology

\section{Introduction}

Wetlands are important ecosystems which perform wide range of hydrological functions such as groundwater recharge and discharge, flood flow alterations, sediment stabilization, water quality etc. [1]. They act like a sponge, soak up water during wet period and release up during dry period [2]. The understanding of hydrological regime and wetland-ground water interactions around any wetland is important. It helps in knowing how a wetland is functioning, its influence on hydrology, hydrochemistry and ecology of the wetland [3]. The hydrology around wetland is strongly influenced by the geological framework, depth and groundwater flow direction below the wetland basin [4]. The permeability of geologic deposits and ground watersurface water flow pattern around wetland directly affect the wetlandgroundwater exchange and indirectly it affects the magnitude of runoff received from the surrounding upland areas [5]. The groundwatersurface water interaction processes are based on the concept of hydrological connectivity [6,7]. This refers to physical linkage of water with rivers, wetlands and surrounding catchment [6,8]. This connectivity allows the exchange of water, solutes and dissolved matter $[8,9]$. The understanding of hydrogeology and wetland- groundwater interactions around Sukhna wetland is important for an effective management of this surface water resource. The present paper provides an overview of subsurface geology, aquifer system, depth to water tables, water level fluctuations, ground water flow pattern and wetland ground water interactions around Sukhna wetland.

\section{Study area}

Sukhna wetland is located within the city beautiful Chandigarh which is surrounded by Siwalik hills (Figure 1). It came into existence in year 1958. It is a manmade freshwater wetland, which is mainly fed by the seasonal rainwater. It is roughly kidney shaped. The mean depth of Sukhna wetland is $3.3 \mathrm{~m}$ and maximum depth of $5.5 \mathrm{~m}$ whereas the length is $1.52 \mathrm{~km}$ and width is $1.49 \mathrm{~km}$.

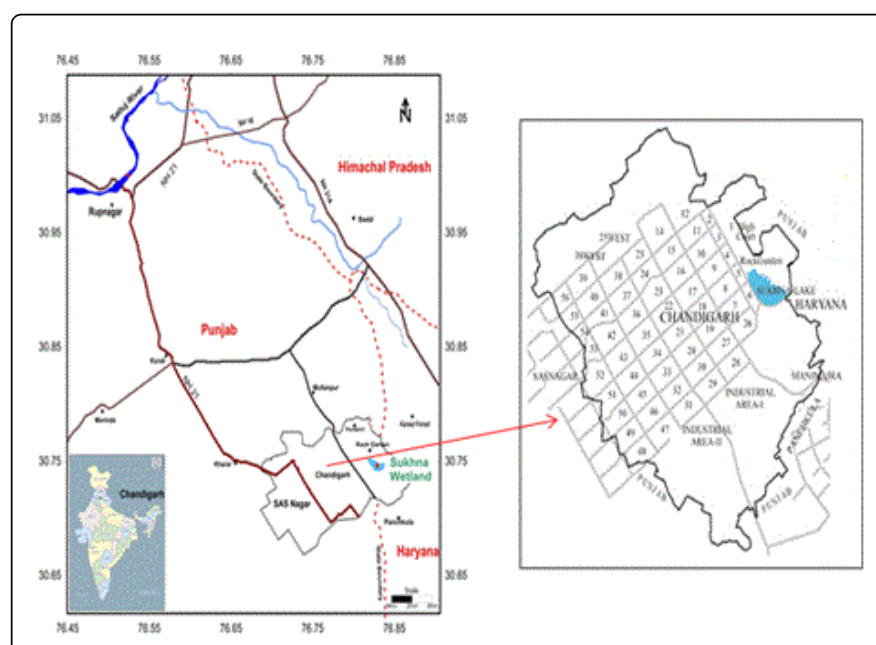

Figure 1: Showing the location of Sukhna wetland in Chandigarh area. 
Citation: Taak JK, Singh KP, Ahluwalia AS (2016) To Study Hydrogeology and Wetland-Groundwater Interactions around Sukhna Wetland, Chandigarh, India. Hydrol Current Res 7: 244. doi:10.4172/2157-7587.1000244

Page 2 of 6

The wetland has a catchment area of $42.07 \mathrm{Sq} \mathrm{km}$, of which $29.08 \mathrm{Sq}$ $\mathrm{km}$ falls in the Union Territory of Chandigarh, $10.22 \mathrm{Sq} \mathrm{Km}$ in Haryana and $2.77 \mathrm{Sq} \mathrm{km}$ in Punjab [10]. The climate of Sukhna wetland has mean maximum temperature of $39.1^{\circ} \mathrm{C}$ during June to minimum temperature of $6.1{ }^{\circ} \mathrm{C}$ during January. The average annual rainfall of the area is $1061 \mathrm{~mm}$ [11].

\section{Geology and geomorphological features}

The regional geological map (Figure 2) around Sukhna (Chandigarh) reveals that rocks of Siwalik system (lower, upper and middle) are exposed in the north east parts of the wetland. Lithologically, these are loose sand stone and silt stone which give rise to sandy and silty soils in the area. The catchment area of Sukhna wetland has rugged terrain, steep slopes and characterized by gully erosion [10].

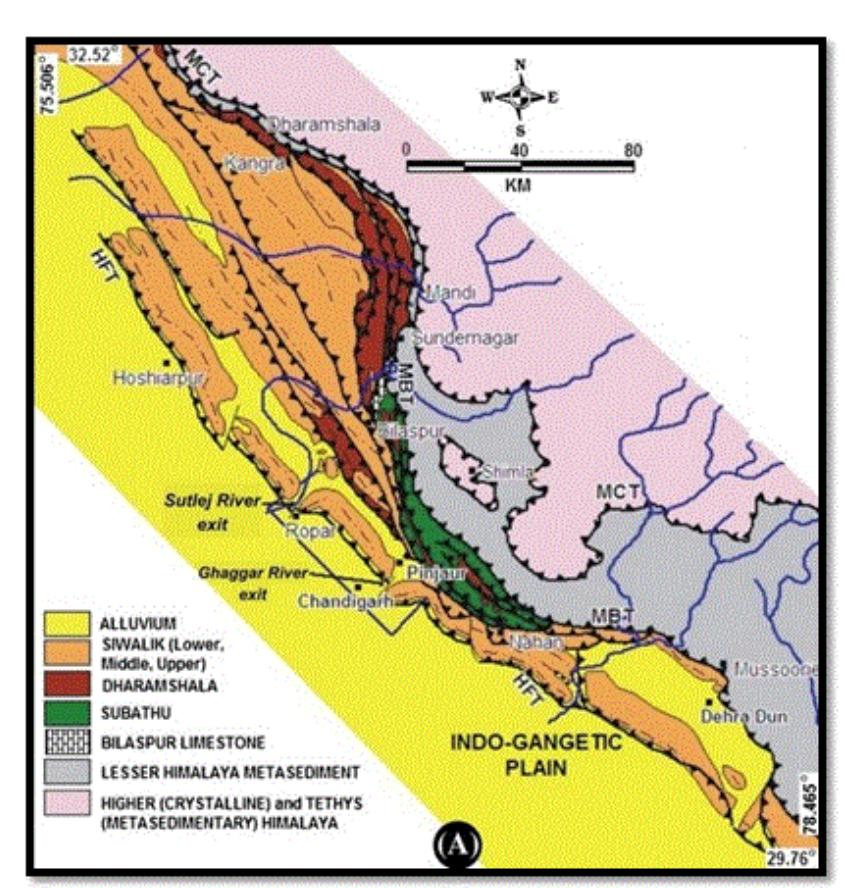

Figure 2: Showing the regional geology of area around Sukhna (Chandigarh) (Source: https://www.academia.edu/12446522/ Matching_geomorphological_study_of_Pinjaur_dun_with_the_arc haeological_reality_of_90_degree_deflection_of_Satluej_River_at_ Ropar).

The detailed geological map (Figure 3) of area around Sukhna wetland in Chandigarh area shows that Sukhna wetland is located over the older alluvium (Q1) of middle to late Pleistocene age. The older alluvium comprises red soil, mixture of clay, silt and sand with kankar, grey medium to coarse micaceous sand with kankar embedded with clay and silt. The newer alluvium (Q2a and Q2b) of Holocene age is confined to areas around Sukhna choe (Figure 3).

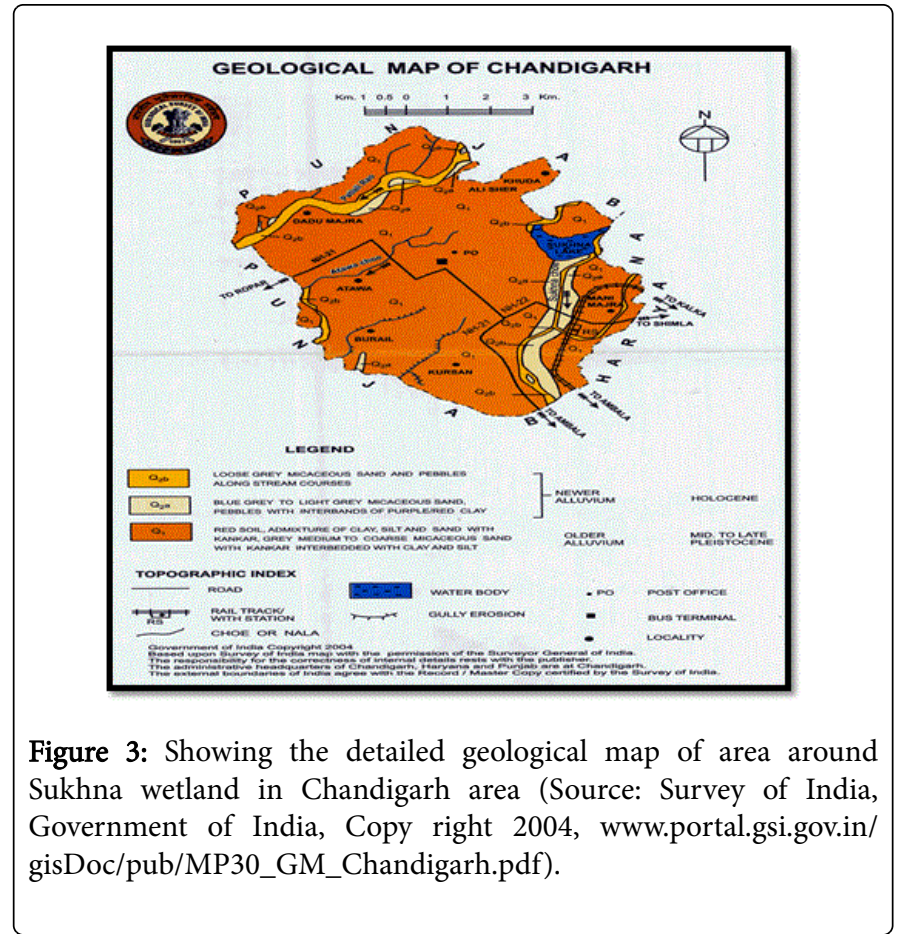

\section{Methodology}

\section{Data collection}

The data was collected from different organizations to study hydrogeology around Sukhna wetland. Some unpublished reports were collected from Central Ground Water Board, Chandigarh [11] to know the water level depth, existing aquifer systems, aquifer characteristics and overall hydrogeological regime around the study area. Year wise water level data was collected from Central Ground Water Board, Chandigarh for different sites in the Chandigarh (from period 1985 to 2013) to monitor water level fluctuations.

\section{Data analysis and mapping}

The lithologs for different bore wells was prepared in Rockwork software. The water level data from period 1985 to 2013 in Chandigarh area was analyzed in an excel spread sheet for monthly and annual values for each bore well site. The hydrographs were plotted for May month (Pre monsoon period) and November month (post monsoon period) using word excel chat for the study area. The elevation contour maps were processed in Surfer 12 to study the ground water flow in the study area.

\section{Results and Discussion}

To understand the hydrogeological regime and wetland-ground water interactions around Sukhna wetland, the subsurface geology, aquifer system, depth to water tables, water level fluctuations and ground water flow pattern in Chandigarh area are studied and discussed below: 
Citation: Taak JK, Singh KP, Ahluwalia AS (2016) To Study Hydrogeology and Wetland-Groundwater Interactions around Sukhna Wetland, Chandigarh, India. Hydrol Current Res 7: 244. doi:10.4172/2157-7587.1000244

Page 3 of 6

\section{Subsurface geology}

Chandigarh city is occupied by semi consolidated formations of upper Siwalik system of middle Miocene age exposed in the northeastern parts. The piedmont deposits lying at the foothills of Siwaliks, comprise of cobbles, pebbles, boulders associated with sand, silt and clay. The piedmont deposits are followed by alluvial plains in the southern parts comprising finer sediments such as sand, silt and clay [11].

The subsurface geology of boreholes drilled around Sukhna wetland i.e., near high court area, sector 6 , sector 1 and Kaimbala has been examined and lithologs of these boreholes are shown in Figure 4. The borehole data indicates that area is underlained by boulders, pebbles, gravels, sand and clay. In the top, the sub surface lithology is dominated by thick zones of boulders, pebbles, gravels, sand and clay ranging in thickness from 3 to $5 \mathrm{~m}$ upto the depth of 80 to $85 \mathrm{~m}$. This lithology is followed by the thick clay bed at 95 to $145 \mathrm{~m}$ depth having thickness of about $15 \mathrm{~m}$. Below $145 \mathrm{~m}$ depth, again the zones of sand, boulders, gravels and clays occur which have thickness varying from 2 to $8 \mathrm{~m}$. All the boreholes examined around Sukhna wetland show similar sub surface geology with minor variations. The depth to static water level ranges from 50 to $80 \mathrm{~m}$ gbl in these drilled boreholes.

The subsurface lithology of Chandigarh area based on exploratory drilling carried out by Central Ground Water Board also reveals similar lithology with minor variations. Central Ground Water Board [11] has also depicted three prominent sand beds which occur (interbedded with clay beds) within a depth of about $100 \mathrm{~m}$ along the Sukhna choe. The upper sand bed is about $15 \mathrm{~m}$ thick and occurs $8 \mathrm{~m}$ below the land surface. Middle sand bed is about $18 \mathrm{~m}$ thick and occurs at depth varying from 21 to $38 \mathrm{~m} \mathrm{bgl}$. The deeper sand bed occurs at depth varying from 39 to $76 \mathrm{~m} \mathrm{bgl}$ and is about $27 \mathrm{~m}$ thick [11]. These beds are more persistent in the downstream direction of Sukhna wetland. The similar lithology has been observed in the sector 6 bore hole well (Figure 4) which is close to Sukhna wetland.

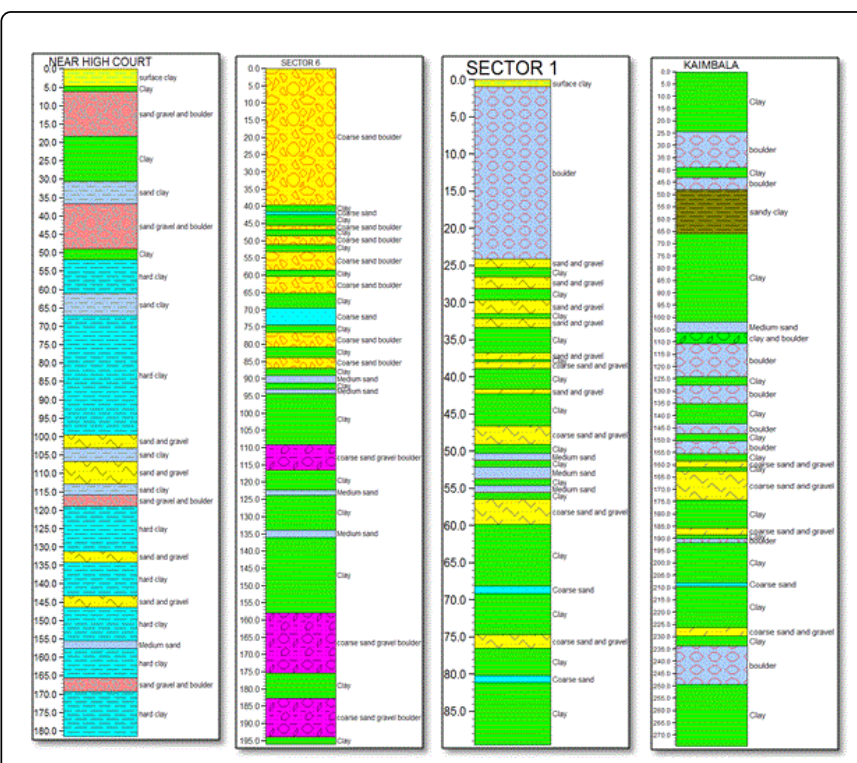

Figure 4: Showing lithologs of boreholes drilled at Near High Court, Sector 6, Sector 1 and Kaimbala locations around Sukhna wetland.

\section{Aquifer system}

In Chandigarh area, there are two distinct aquifer systems - shallow and deep. The shallow or upper aquifers are generally unconfined upto $80 \mathrm{~m}$ bgl in Manimajra area as revealed by drilling data of CGWB [11]. In the other parts of the city the semi confined conditions prevail upto 20-30 m below the land surface. Deeper confined aquifers exist below $90 \mathrm{~m} \mathrm{bgl} \mathrm{in} \mathrm{Manimajra} \mathrm{which} \mathrm{is} \mathrm{close} \mathrm{to} \mathrm{Sukhna} \mathrm{wetland} \mathrm{[11].}$

In Chandigarh, the aquifer performance test conducted by Central Ground Water Board [11] reveals that transmissivity ranges from 74 to $590 \mathrm{~m}^{2}$ /day for deeper aquifer system (100-300 m depth). In shallow aquifer upto $100 \mathrm{~m}$ depth it ranged from 70 to $466 \mathrm{~m}^{2} /$ day [11]. The storativity of deeper ranged between $1.5 \times 10^{-4}-7.5 \times 10^{-4}$, indicating confined nature of aquifer system [11].

\section{Depth to water table}

The Figures 5A and 5B indicates the water level depth for deep and shallow aquifer in Chandigarh. The depth to water level during premonsoon season in the shallow aquifer varies between 2 to above $20 \mathrm{~m}$ bgl (Figures 5A) whereas in the deep aquifer system the water level lies between 10 to above $40 \mathrm{~m}$ bgl (Figure 5B) [11]. Sukhna wetland lies in the northeastern side of Chandigarh where depth to water level for shallow aquifer ranged above $20 \mathrm{~m} \mathrm{bgl}$ and in deeper aquifers ranged above $40 \mathrm{~m}$ bgl [11].

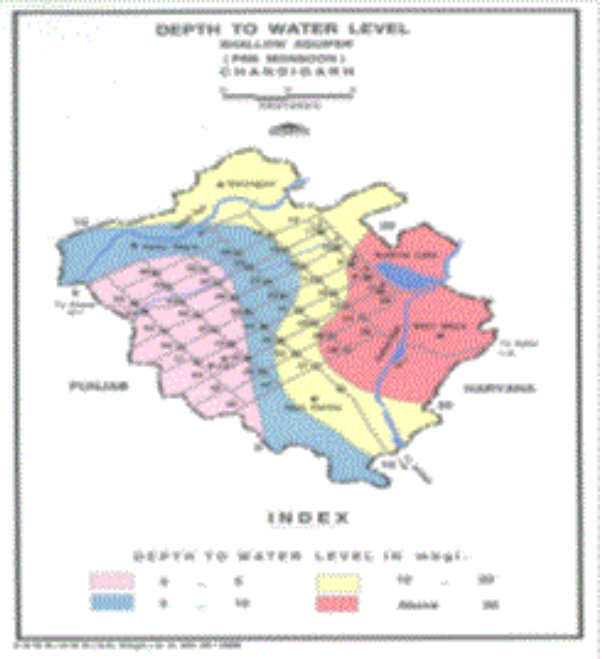

Figure 5A: Showing depth to water level for shallow aquifers (Pre Monsoon) in Chandigarh area. 
Citation: Taak JK, Singh KP, Ahluwalia AS (2016) To Study Hydrogeology and Wetland-Groundwater Interactions around Sukhna Wetland, Chandigarh, India. Hydrol Current Res 7: 244. doi:10.4172/2157-7587.1000244

Page 4 of 6

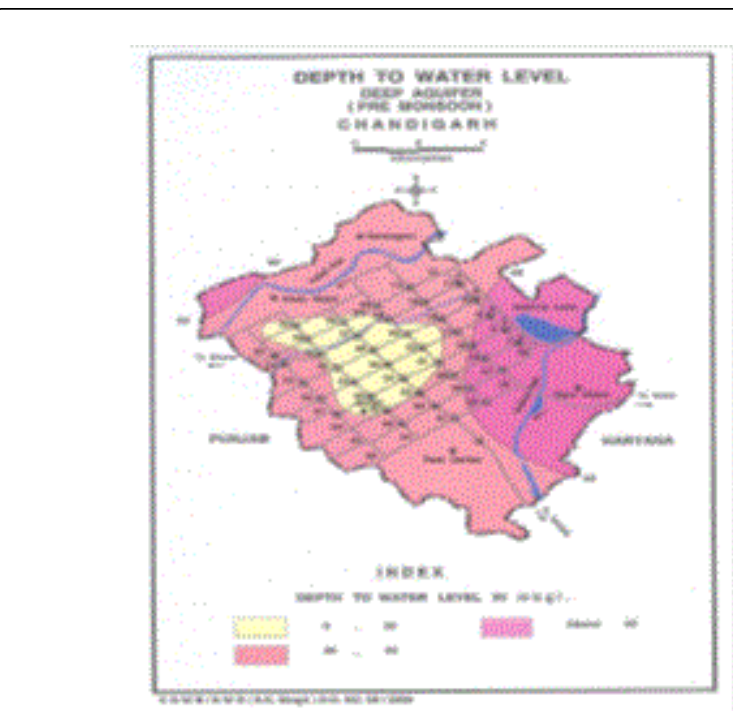

Figure 5B: Showing depth to water level for deep aquifers (Pre Monsoon) in Chandigarh area.

\section{Water level fluctuations}

The long term water level fluctuations for two seasons i.e., May (Pre monsoon) and November (Post monsoon) months has been studied in Chandigarh area. The hydrographs plotted (Figures 6 and 7) for May month (Pre monsoon) and November month (Post monsoon) reveal the declining trend in water level in deep aquifers in most of the observation wells and it is attributed due to the over exploitation of groundwater by tubewells installed by the Public Health Department, UT, Chandigarh for providing domestic water supply. Table 1 shows the rate of fall/rise in water levels in observation wells near to Sukhna wetland in Chandigarh area for the period 1985-2013 which indicates that in all the locations the water levels are declining except in sector $39 \mathrm{D}$ well, where the water level is showing the rising trend due to local variations. On the whole, the water levels in the study area show the declining water level trend.

\begin{tabular}{|c|c|c|c|}
\hline $\begin{array}{c}\text { S } \\
\text { No }\end{array}$ & Location & \multicolumn{2}{|c|}{ Rate of fall/rise in water level (cm/year) [From } \\
\hline & May (Pre Monsoon) & November (Post Monsoon) \\
\hline 1 & Sector 12 & -32.28 & -18.21 \\
\hline 2 & Sector 3 & -81.21 & -73.6 \\
\hline 3 & $\begin{array}{c}\text { Sector 37 } \\
\text { D }\end{array}$ & -12.32 & -11.96 \\
\hline 4 & $\begin{array}{c}\text { Sector 21 } \\
\text { D }\end{array}$ & -16.82 & -25.39 \\
\hline 5 & $\begin{array}{c}\text { Sector 31 } \\
\text { D }\end{array}$ & -26.78 & -32.78 \\
\hline 6 & $\begin{array}{c}\text { Sector 10 } \\
\text { C }\end{array}$ & -34.35 & -4.96 \\
\hline 7 & $\begin{array}{c}\text { Sector 44 } \\
\text { D }\end{array}$ & -9.28 & \\
\hline
\end{tabular}

\begin{tabular}{|c|c|c|c|}
\hline 8 & $\begin{array}{c}\text { Sector } 39 \\
\mathrm{D}\end{array}$ & 19.03 & 30.42 \\
\hline
\end{tabular}

Table 1: Showing the rate of fall/rise in water levels in observation wells located near to Sukhna wetland.

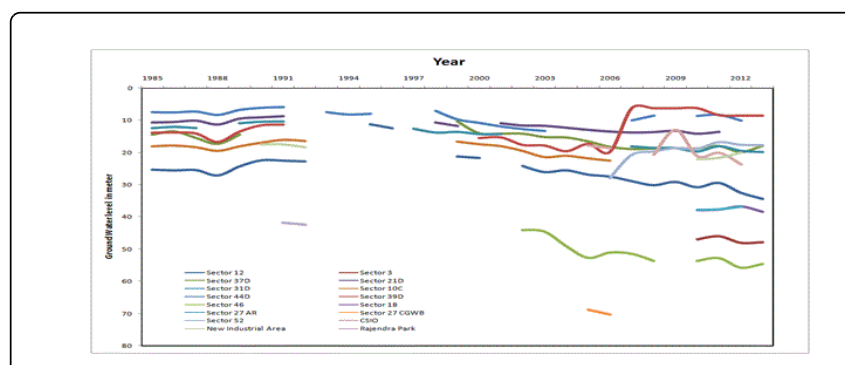

Figure 6: Showing hydrograph for May (Pre monsoon) month in Chandigarh area.

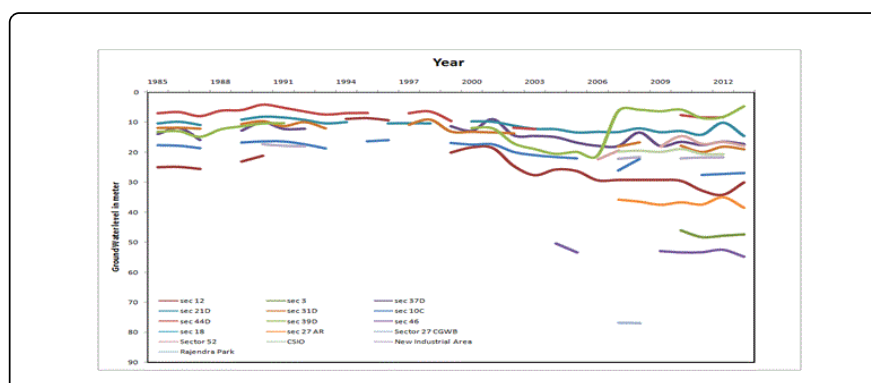

Figure 7: Showing hydrograph for November (Post monsoon) month in Chandigarh area.

\section{Water table elevation contours}

The water table elevation contour maps for May and November months in Chandigarh are shown in Figures 8A and 8B for years 1986, 1991, 1999, 2005 and 2012. These maps reveal that the regional ground water flow direction is from northeast to southwest. Further, the regional groundwater flow direction does not show any significant temporal variations.

\section{Wetland-groundwater interactions}

On the basis of hydrogeological regime discussed above, it can be inferred that Sukhna wetland is contributing recharge in the upper shallow aquifer system as revealed by water table contour maps prepared. The water table contour maps (Figures $8 \mathrm{~A}$ and $8 \mathrm{~B}$ ) reveal the groundwater flows from Sukhna wetland area towards the central part of Chandigarh and below. However, no appreciable rise in water levels has been observed in upper shallow aquifer around Sukhna wetland as the subsurface groundwater flow is towards south and south west directions and exploitation of groundwater by shallow tube wells. Deeper aquifer system is not influenced by the Sukhna wetland and water levels of this aquifer system show declining water level trend due to over exploitation of groundwater by water supply tubewells installed by the Public Health Department, UT, Chandigarh for domestic use. 
Citation: Taak JK, Singh KP, Ahluwalia AS (2016) To Study Hydrogeology and Wetland-Groundwater Interactions around Sukhna Wetland, Chandigarh, India. Hydrol Current Res 7: 244. doi:10.4172/2157-7587.1000244

Page 5 of 6

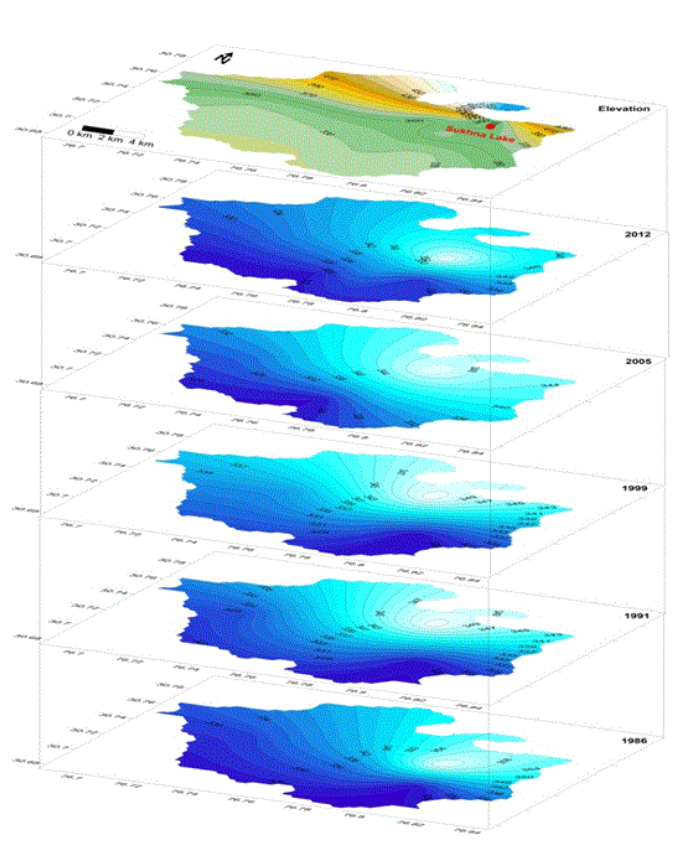

Figure 8A: Showing water table elevation contour map of Chandigarh for May month.

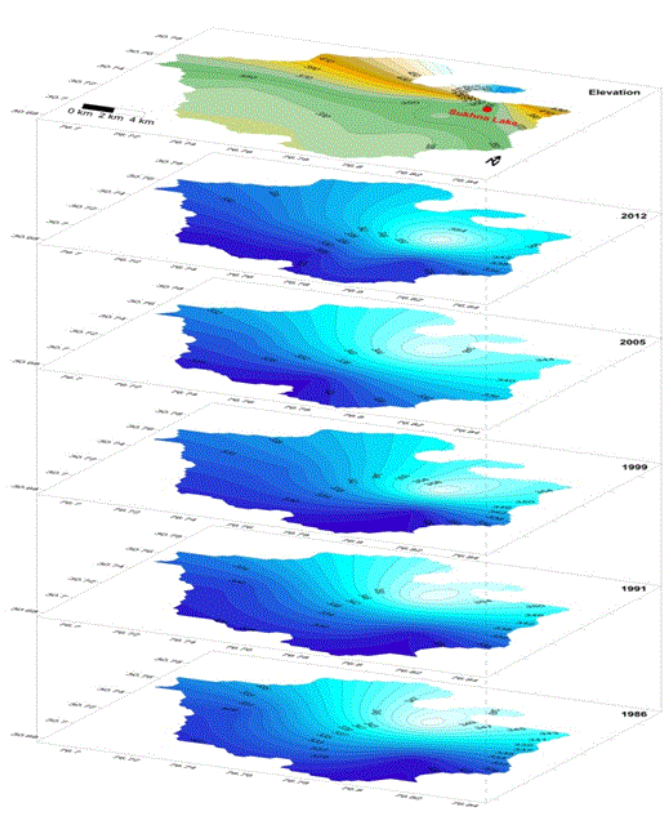

Figure 8B: Showing water table elevation contour map of Chandigarh for November month.

\section{Conclusions}

The subsurface geology of boreholes drilled around Sukhna wetland i.e., near high court area, sector 6 , sector 1 and Kaimbala indicate that area is underlained by boulders, pebbles, gravels, sand and clay. In the top, the sub surface lithology is dominated by thick zones of boulders, pebbles, gravels, sand and clay ranging in thickness from 3 to $5 \mathrm{~m}$ upto the depth of 80 to $85 \mathrm{~m}$. This lithology is followed by the thick clay bed at 95 to $145 \mathrm{~m}$ depth having thickness of about $15 \mathrm{~m}$. Below $145 \mathrm{~m}$ depth, again the layers of sand, boulders, gravels and clays occur which have thickness varying from 2 to $8 \mathrm{~m}$. All the boreholes examined around Sukhna wetland show similar sub surface geology with minor variations. There are two type aquifer systems i.e., shallow and deep. The depth for shallow aquifer ranged $2-20 \mathrm{~m} \mathrm{bgl}$ and in deeper aquifers ranged 10 above $40 \mathrm{~m} \mathrm{bgl}$ in study the area. The water level fluctuations for the period 1985-2013, indicates the declining water level trend in both the seasons i.e., pre monsoon (May) and post monsoon (November) due to over exploitation by tubewells installed by the Public Health Department, UT, Chandigarh for providing domestic water supply. The water table elevation contour maps for May and November months in Chandigarh for years 1986, 1991, 1999, 2005 and 2012 reveals that the regional ground water flow direction is from Northeast to Southwest and there in no significant temporal variations in regional ground water flow direction. On the basis of hydrological regime study around Sukhna wetland it is inferred that no appreciable rise in water levels has been observed around Sukhna wetland but it is contributing recharge in the upper shallow aquifer system in the central part of Chandigarh and below as the subsurface groundwater flow is towards south and south west direction. It is recommended to keep a regular check on the over exploitation of groundwater around Sukhna wetland and areas around it.

\section{Acknowledgements}

The authors are grateful to the Head, Department of Geology and Department of Environment Studies, Panjab University, Chandigarh for providing the necessary facilities for our research work.

\section{References}

1. Bullock A, Acreman M (2003) The role of wetlands in the hydrological cycle. Hydrology and Earth System Sciences 7: 358-389.

2. Bucher EH, Bonetto A, Boyle T, Canevari P, Castro G, et al. (1993) Hidrovia-an initial environmental examination of the Paraguary-Parana waterway. Wetlands for the Americas Publication No. 10, Manomet, MA, USA, p: 72 .

3. Coram JE (1996) Groundwater-surface water interactions around shallow lakes of the western district plains, Victoria. A thesis submitted to the University of Melbourne in partial fulfillment of the requirements for the Degree of Master of Science.

4. Winter TC, Woo MK (1990) Hydrology of lakes and wetlands. In: Wolman MG and Riggs HC (eds.). Surface water hydrology: Boulder, Colo. The Geological Society of America, pp: 159-187.

5. Lee TM, Haag KH, Metz PA, Sacks LA (2009) Comparative Hydrology, Water Quality and Ecology of Selected Natural and Augmented Freshwater Wetlands in West-Central Florida. US Geological Survey Professional Paper 1758, p: 152.

6. Bracken LJ, Croke J (2007) The concept of hydrological connectivity and its contribution to understanding runoff dominated geomorphic systems. Hydrol Process 21: 1749-1763.

7. Lexartza-Artza I, Wainwright J (2009) Hydrological connectivity: Linking concepts with practical implications. Catena 79: 146-152.

8. Anibas C, Verbeiren B, Buis K, Chormanski J, De Doncker L, et al. (2012) A hierarchical approach on groundwater-surface water interaction in wetlands along the upper Biebrza River. Poland Hydrol Earth Syst Sci 16: 2329-2346.

9. Ward JV (1997) An expansive perspective of riverine land-scapes: pattern and process across scales. River Ecosyst 6: 52-60. 
Citation: Taak JK, Singh KP, Ahluwalia AS (2016) To Study Hydrogeology and Wetland-Groundwater Interactions around Sukhna Wetland, Chandigarh, India. Hydrol Current Res 7: 244. doi:10.4172/2157-7587.1000244

Page 6 of 6

10. Singh Y (2002) Siltation Problems in Sukhna Lake in Chandigarh, NW India and Comments on Geohydrological Changes in the Yamuna-Satluj Region. ENVIS Bulletin: Himalayan Ecology and Development 10: 18-31.
11. Central Ground Water Board (2007) Report on Chandigarh UT, Central Ground Water Board, Ministry of Water Resources, Government of India, North Western Region, Chandigarh. 